\title{
Effect of Internal and External Environment of Human Capital Development (Empirical Study on Manufacturing Company Gopublik in Indonesia)
}

\author{
DR. H. Saban Echdar, SE. M.Si \\ STIE Nobel Indonesia Makassar
}

\begin{abstract}
This study uses object manufacturing companies going public in Indonesia, with a sample of 12 companies that tedaftar in Indonesia Stock Exchange. Each sample of 10 companies was taken at the level of managers and staff. This study sought to test and analyze whether the internal and external environment influence the development of human capital through intervening variables planning and human resource management, employee improvement, education and training, and recognition of employee performance and employee satisfaction .

Results of this study indicate that first, the external environment has a positive and significant impact on the planning and management of human resources, education and training, and the development of human capital, but has no effect on the increase in employees, employee performance and recognition, and employee satisfaction. Second, the internal environment has a positive and significant impact on the planning and management of human resources, employee improvement, education and training, employee performance and recognition, employee satisfaction, and the development of human capital. Third, planning and human resource management, employee improvement, education and training, employee performance and recognition, employee satisfaction has a positive and significant impact on the development of Human Capital.

Testing also proved that the development of human capital such as intellectual capital, emotional capital, social capital, fortitude capital, moral capital and health capital can be increased through the use of the external environment and internal environment, and improve the planning and management of human resources, employee improvement, education and training, performance and employee recognition and employee satisfaction.
\end{abstract}

Keywords: external environment, internal environment, human capital development.

\section{Introduction}

Development of human capital for the organization is essentially an investment and an investment in human capital expenditures aimed at improving the production capacity of the human being, through the improvement of health, education and training. Logical reasons can be put forward is that the workforce is healthy, educated and skilled labor force will be productive and further increase in productivity means increased return. With good human capital, the organization will have a competitive force and would be difficult to replicate, so the sources of competitive success of such traditional production process technology, market protection, access to financial resources and economies of scale should be more efficient.

It is perting in manufacturing companies is to invest in the form of capital equipment to remain competitive and adapt to changes in technology. Leaving the factory and the machines become obsolete is a disaster for the company. But capital equipment can not operate efficiently if the operator is not capable and skilled to handle and run the machines. It is increasingly important to be emphasized, given the changes in technology as a result of external environmental changes happening so fast that cause rapid equipment and using it requires a professional handler in the company of humans as human capital.

The concept of human capital is essentially considers humans is a form of capital or capital as other forms of capital, such as machinery, technology, land, money and material. Human beings as human capital is reflected in the form of knowledge, ideas (ideas), creativity, skills and productivity. Unlike other forms of capital are only treated as tools, human capital can be invested themselves through various forms of investment in human resources, including formal education, informal education, work experience, kesehaan and nutrition and transmigration (Fattah, 2004).

Human capital is the ability possessed by humans and if managed properly valued as an investment. Training and human resource recruitment is an investment, which plays an important role in all matters concerning the activities of manufacturing companies going public. Walaupu tools used cangkih with high technology, but without the role of human resources qualified, professional and skilled as human capital, then a business will not grow well and (sustainable). 
According to Mayo (2000), measuring the performance of the company from a financial perspective is very accurate but it is actually the basis of the financial value drivers are human resources / human capital with all the knowledge, ideas, and innovations that have. Besides human capital is at the core of a company.

Company comprised of individuals who work together to achieve certain goals and the organization will not run if there is no individual in it.

In a situation that increasingly sharp competition, each organization is required to have a competitive advantage in order to compete and still exist in the market. One of the potential competitive advantage of an organization lies in the extent to which management utilize, manage, control and utilize both its assets and intangible assets optimally tangibe (Smith, 1998). In this regard, Anderson and Finkelstein (1996) stated that in today's competitive environment, human capital increase the company's knowledge is one of the intangible assets are highly strategic for the company to achieve a competitive advantage.

In line with this, Martina Dwi Praise Astri Ongkorahardjo, et al, (2001) stated that human capital is seen as a strategic element for the management and performance of the company's human resources contributed greatly to the creation of competitive advantage (competitive advantage). The ability to manage human resources as an important asset to the success of companies such as skills, knowledge, abilities and behaviors of humans needed to achieve competitive advantage, because at its core is people who will implement the company's strategy.

Strategic human capital consists of four attributes, namely usefulness, behavioral uncdertainty, firmspecificity and spread of strategic human capital. Unefulness of strategic human capital is said to be useful because it is important for companies to create efficiencies and allow the company to be more effective. Behavioral uncertainty that human capital is difficult to imitate a competitor if the tasks and work performed can not be observed by competitors. Firm-specificity of human capital strategic indicate a level of firm-specific knowledge is high. Spread of strategic human capital is the knowledge and skill of human capital spread across firms (Barney \& Wright, 1991).

The key advantages of human capital by Setyanto (2004) also comes from the uniqueness of its value, because the value of human capital will not depreciate, the value will appreciate it if always being developed and treated appropriately. Therefore, according to Flamholtz and Lacey (1981), firms can use HR management in various ways to increase human capital. Companies can buy human capital in the market or lead to increased human capital internally or companies can outsource human capital plowing through another company.

According to Dave Ulrich (1997), there are four roles of human capital in the contemporary era is a major reference in the majority of the company under the sun. The first role is an expert in administration (management of firm infrastructure), both play a role in the region and contributing to the winner (management of the employee contribution), the third role as agents of change and transformation of the company (management of transformation and change) and a fourth role as partners in determining corporate strategy (strategic management of human resources).

Human capital has five components namely individual capability, individual motivation, leadership, the organization climade and workgroup effectiveness. Each component has a somewhat different role in creating human capital firm that ultimately determines the value of the company. Human capital is important because it is a source of innovation and renewal strategies that can be obtained from brainstorming through laboratory research, dream management, process re-engineering and improvement or development of worker skills. In addition, the human capital to add value in the company every day, through motivation, commitment, competence and effectiveness of teamwork. The added value that can be contributed by workers in the form of: development of competencies possessed by the company, the transfer of knowledge from workers to firms and cultural change management (Mayo, 2000 in Rachmawati et.al, 2004)

In this regard, Chen and Lin (2003) stated that the expenditure in connection with the company's human resources should be viewed as an investment in human capital. View of the organization that is the cost of human capital management, should be abandoned, it means investing in human resources (human capital) is seen not as the current costs (current expences) is borne by the company, but rather as an investment in assets that have value in the future as well the value that has been created. The implication is that if the condition of the company experienced a decline / reduction, cost related to human resources is no longer seen as a cost that must be trimmed first.

Thus the employee is no longer a "cost", but as "human capital" that add value to the company, with the innovations. Results of human transformation is seen as an indicator of success is the cost and efficiency, turned into a 'corporate asset', and indicators of success are innovation and value creation. This is in line with the teachings of Islam which teaches that the human resources within a company is one of the capital, not as a cost unit, thus handling human resources as human capital, is not something new in the Islamic economic activity (Rival Rival,

2009).

Contrary to the statement-the statement above, it is clear that human capital is a strategic asset because the company has an advantage compared to the assets that other companies, such as physical capital and 
organizational capital. Human capital has managerial competence, ie the ability to formulate a vision and strategy of the company as well as the ability to direct other resources in order to realize the vision and implement strategies perusahhaan. Investment in plant, technology, new products, distribution and marketing systems and strategies to function properly if it gets a touch of human capital.

Therefore the main steps that should be carried out by the organization, especially manufacturers have companies going public is to change the mindset, of managing expenses to the creation of value for human capital invested in the company's knowledge and expertise, which vote markets by looking at the company's activities, and this is reflected in value added generated. Optimizing the role of human capital in the condition where the level of competition among manufacturing firms going public is very tight and very powerful changes at this time, is not inevitable. Human capital in the region should play a more intelligent and challenging, the company's partner strategy, bodyguard change and corporate transformation actors. Without this intelligent role be prepared to cover because companies can not compete because the man is not competent and professional workers.

Although human capital to boost the competitiveness of the company, but unfortunately in many companies, including manufacturing companies going public, human resources are still rarely gets major attention. Many corporate leaders are less aware that corporate profits actually come from human capital, this is due to more companies aiktivitas viewed from a business perspective alone. Corporate leaders do not see the company as a unit that contains the unique knowledge and skills, or a set of uniqueness of its assets that can differentiate a product or service from its competitors. According to Dwi Praise Simpson (2001), there are still manufacturing company leader who has gone public is still not aware of the importance of human resource development as human capital in improving my performance and competitiveness of the company. Efforts are underway to improve the company's manufacturing capabilities and professionalism of the company's human resources through training, including selective recruitment process has been done, even the costs incurred for the program has increased every year. However, the cost incurred by the company for the program is still regarded as a burden (cost) of the company, has not been considered as an investment in human capital.

That requires a system for measuring human capital, its development and influence business outcomes tehadap so the company is able to avoid the negative tendencies in the development of human capital investment program. To make man as human capital in manufacturing companies going public, it is necessary to study the factors that influence the development of human capital, how ekstenal and internal environmental influences on the development of human capital. On the basis of this phenomenon, this study sought to clarify the extent to which the external environment, internal environment influence the development of human capital, through an intervening variable: the planning and management of human resources, employee improvement, education and training, and recognition of employee performance and employee satisfaction in manufacturing firms go -public in Indonesia.

Based on the description of the background of the problem, the research problem can be formulated as follows: 1) Is the external environment influence the development of human capital variables through planning and human resource management, employee improvement, increase in personnel, education and training, and recognition of employee performance and employee satisfaction, and 2) whether the internal environment influence the development of human capital variables through planning and human resource management, employee improvement, increased personnel, education and training, and recognition of employee performance and employee satisfaction.

The purpose of this study is: 1) prove that the external environment affects the development of human capital variables through planning and human resource management, employee improvement, increase in personnel, education and training, and recognition of employee performance and employee satisfaction, 2) prove that the internal environment influence the development human capital variables through the planning and management of human resources, employee increase, an increase in personnel, education and training, and recognition of employee performance and employee satisfaction.

\section{Human Capital}

The term human capital or human capital which is popularly called, was first widely introduced by Theodore W. Shultz in his address to the American Economic Association in 1961. Shultz thinking concept in 1961, which was then elaborated by Becker in 1964 in Nan Lin (2000), defines human capital as: "Value added to a Laborer Laborer when acquires the knowledge, skills, and other assets useful to the employer or firm in the production and exchange process ... human capital is the added value embedded in the Laborer Themselves. Typically, human capital is operationalized and Measured by education, training, and experience ".

Adam Smith (2005) defines human capital is: "The greatest improvement in the productive powers of labor, and the greater part of the skill, dexterity, and judgment with roomates it is any where directed, or applied, seem to have been the effects of the division of labor ". Burud and Tumolo (2005), defines human capital is: The 
application of intellectual capital (knowledge, skills, and talent) plus relational capital (connections and relationships with customers, peers, and external associates) in the oursuit of an organization's goals, to innovate (create new products and new services, and to improve business process) ".

Shultz and Becker, and Adam Smith (2005) is very explicit, saying that human capital is inherent to the individual. While Burud and Tumolo (2005) does not expressly state that the human capital that is attached to the individual. They even put the relational capital as a component of human capital. Clear here that the concept of human capital is not a new one according to a Western perspective. Economic figures in Western industrial era tried to highlight the interests of the capital but it was still seen as important because it forms a free economy at that time the more devote to commodities. But the interests of human capital as the foundation of economic growth is seen as essential at this time so that the resulting terms that anyone who menafi and to put away its human capital as one of the components of economic growth is like giving an explanation regarding Soviet ideology without hooking up with Karl Marx (Schultz, Theodore, W, 1971).

The term human capital can be interpreted as the economic value of the relevant human with the ability, knowledge, ideas, energy and commitment (Schermerhorn, 2005). There are 2 things that a key principle of focusing on the idea of human capital (GAO, 2000), namely: (1) human resources are assets whose value can be enhanced through investment. With that investment company's value can be maximized by managing risk. With the increase in the value of human resources will improve the performance of the organization and be of value to customers and stakeholders. (2) the policy of the organization must be aligned in support of a shared vision (Share the Vision) as a mission, a vision for the future, core values, goals and objectives, and strategies that the organization has set the direction, expectations for the organization and its people. All human capital policies are designed, implemented and adapted to how well they participate in creating value with him.

George Bollander, Arthur Scott Snell and Sherman (2001) in Richard L.Daft (2006) states that human capital is the economic value of the knowledge, experience, skills and abilities of employees. To build human capital, human resources management to develop strategies to ensure that the workforce has the knowledge and superior skills. This means finding and recruiting the best talent, enhance their skills and knowledge with the training program and the opportunity for personal and professional development as well as provide compensation and employee benefits increased efforts to share knowledge and provide appropriate rewards to people for their contributions to organization.

Human capital by Fitzens (2000) is a combination of the following factors: the properties of a person he was born to the job: intelligence, energy, general positive attitude, reliability, commitment, a person's ability to learn: talent, imagination, creativity, and what is often referred to as a street smart, savvy (intellect, intelligence) and one's motivation to share information and knowledge: team spirit and goal orientation.

Human capital is the accumulation of capabilities, capacities and opportunities of the members of the organization. Capability is the ability of members of the organization to do something, whether it is the capacity and opportunities, in order to achieve the desired goal. Capacity is more focused on what can be done by members of the organization, while more opportunities on the options available to members of the organization to get the award, including salary, bonuses and so the result of the use of its capacity, so that capability is formulated as an opportunity capacities x (Dharma, 2004).

According to Thomas A. Stewart (1997), the economic value of human capital is not in doubt. Many large companies have proved this, call it, Taco.Inc, Kodak, GE, and IBM. There are three important things to be thinking in human capital, namely: (1) the importance of human assets, (2) how to improve human capital and (3) benefit from increased human capital itself. Further Stewart (1997) suggests, human capital can grow when an organization can leverage the knowledge of people and make more people aware that his ability can be exploited organization.

Mayo (2000), states that human capital has five components, each component has a different role in creating the company's human capital, which in turn determines the value of a company, namely: 1) Individual capability. Knowledge / skill / experience / network; ability to Achieve results, potential for growth; and what they bring into work from other parts of their life, 2) individual motivation. Aspirations, ambitions and drive; work motivations; productivity, 3) leadership. The clarity of vision of the top management and thei ability to communicate it and behave in a way that is consistent with it., 4) the organizational climate. The culture of the organization, especially in its freedom to innovate, openness, flexibility and respect for the individual. and 5) Effectiveness Workgroup. Supportiveness, mutual respect, sharing in the common goals and values.

According to Dave Ulrich (1997), there are four roles of human capital in the contemporary era is a major reference in the majority of the company under the sun. The first role, is an expert in administration (management of firm infrastructure), the second role, playing in the area contribute and be a winner (management of the employee contribution), the third role, as agents of change and transformation of the company (management of transformation and change) and The fourth role, as partners in determining corporate strategy (strategic management of human resources). 
Fitz-Enz in Setyanto (2004) describes human capital as a combination of three main factors, namely (1) the character or nature brought to the job, such as intelligence, energy, positive attitude, reliability and commitment, (2) the person's ability to learn, namely intelligence, imagination, creativity and talent, and (3) the motivation to share information and knowledge, the team spirit and goal orientation. Julius Tahija (2001), the founder of Bank Niaga and owner Austindo Group, said that the building is more important than building human resource managers lainnya.Keyakinan requires human capital and founded his company is able to influence the division-division and other employees to align with the strategy of human capital that has been agreed.

Furthermore Setyanto (2004) states that there are six elements that the successful management of human capital in the application of competency-based human capital is as follows: The first, and the other elements are the basis of credible management. Without credibility of human capital management, then a pretense made-up if the company wants to implement a competency-based human capital. Is this credible characterized by: (a) always results oriented with high integrity, (b) capably share information, (c) build a relationship based on mutual trust in each division, and (d) perform the functions of human capital with the attitude to always grow.Second, implementing a proven corporate culture, and translates it in day-to-day operations. His role as a facilitator of change, cultural design, and aligning corporate culture to personal culture. Corporate culture as a 'tool' to move the entire community organizations become very important element in this CBHRM.Third, as a talent manager and designer organization. Hottest issues now plague the country's human capital division is talent management and organization development into the third element. In this element of managing human capital play in the area of training, development and career paths for employees. Do not miss the traditional role that should not be violated is to design a system of rewards (reward system) that is fair to employees.

Fourth, as an architectural strategy to know and understand the level of implementation of change management. Not incorrect to say that the company still wants to develop an ongoing basis must be friends with change. When a corporation decides to change, human capital management should be a major garda escort duty changes laid the foundations wade strategy changes. Fifth, acting as a contributor to the business success of the business as a whole. In this element, human capital management plays a role in interpreting the social context of business, size of business values, business technology and business value chain. Or simply as an advocate for the other divisions in order to be successful in running a sustainable business. Sixth, is the executor of the operation that played at the daily work in the area of managing people and organizations. The role of such common division is run by human capital, which is implementing the policy work (systems and procedures, job descriptions, appraisal systems). Along with the growth of information technology, operations executor must also be skilled in running the human capital technology, whatever program you use.

Contrary to the notion of human capital and the arguments put forward by the experts, the authors formulate the notion of human capital as: a set of skills, knowledge, competencies and behaviors as well as various intelligence attached to the ability of an individual that causes them to work more creatively and productively, which then generates economic value-added benefits the organization in which he works well for himself sendiri.Human capital is an important factor in an organization, which should continue dikreasi for the creation of innovation so as to provide a significant contribution to the advancement and development of the organization, both organizations social and business organizations, as well as generating economic value as a reference for the usefulness of the individual.

Thus human capital is a very important component in the manufacturing companies going public in Indonesia, because the man with all his ability when deployed in total and dimanaj properly, will result in outstanding performance, while providing a significant contribution to the creation of competitive advantage (competitive advantage). The ability to manage human resources as an important intangible asset for the success of companies such as skills, knowledge, abilities, and behaviors of humans is necessary, because at its core is people who will implement the company's strategy.

\section{Research Methods}

The approach of this research is explanatory research that describes the symptoms caused by an object of research. Researchers tried to find an answer to the phenomenon of a problem (Subiyanto, 1994:23). This design was done because the research process undertaken to confirm and test the relationship between variables (causal research), which will specifically test the hypothesis in a structural equation. As stated by Zikmund (1997) that a causal research is research designed to identify the causes and effects of each variable on the relationship between research problems telaj clearly defined.

This study used data pooling the merger between the data time series and cross section to obtain the value of the influence of external environmental factors, internal environment, planning and human resource management, employee improvement, education and training, and recognition of employee performance and employee satisfaction towards the development of human capital. Data were collected by survey method is to 
select a sample of the population that is based on certain characteristics. The research was carried out for 3 (three) months from October s/d in December 2011, with the location of research on companies listed in Indonesia Stock Exchange.

The type of data that is qualitative data obtained in the form of numbers (numeric), in the form of reports. Sources of data used in this study is secondary data is data obtained in writing in the form of company documents and other written information that have a direct connection with the problem under study. Data sources: corporate employment report sample period 2006-2010, the company Company profile sample period 2006-2010, Indonesian Human Resources Directory Jakarta in 2006 -2010, journals and scientific papers related to the research.

Data was collected with the study of literature in the form of books, journals and reports related to the research and documentation done by accessing the official website of the Indonesia Stock Exchange and the company sample. Quantitative data obtained were then combined with the results of questionnaires and interviews with selected respondents. The study population was all Manufacturing Companies Go Public is listed on the Indonesia Stock Exchange (BEI), ie as many as 151 companies (ICMD, 2010). As a public company, the company has the financial statements together with the notes to the financial statements are deemed sufficiently complete and made public in the media.

Sampling technique in this study was purposive sampling based on the consideration that sample/specific criteria in accordance with the purposes of research (Cooper and Emory, 1997:245). Once classified based on the completeness of the data and the level of activity on the IDX, obtained a sample of 12 companies. Sampling is based on the following criteria: a) the companies studied are listed manufacturing company at least one year prior to the year of observation, and its shares are still listed on the Stock Exchange until the end of the study (2011), b) has at least 100 employees, have a program education and training are clear for each year and have the employee performance appraisal system, c) use the 20-30 of each month as the date of the payroll period and, d) use of banking services in the employee salary transfer system.

Manufacturing companies in and meet the criteria to be sampled as many as 12, the Aqua Golden Missipi, Multi Bintang Indonesia, Gudang Garam, Hanjaya Mandala Sampoerna, Bayer Indonesia, Goodyear Indonesia, Semen Gresik, Indonesia Food Past, Ultra Jaya, Indonesia Unilever, Bata Shoes and Tempo Scan Pacific. To determine the sample size, the research Sugiyono Roscoe (2007) says that: a) a decent sample size in the study from 30 to $500, \mathrm{~b}$ ) when the sample is divided into categories, the number of members in the category of at least 30 samples, c) where the research using multivariate analysis (Regression and Correlation) the total sample of 10 times the number of variables, d) If a simple experimental study, the number of samples in groups of 10 to 20 .

Based on the size, population respondents from each company established 10 responsen sample using purposive sampling method, with consideration of selected populations are: 1) their status as manager of the company, and has a staff, 2) staff working at each level manager at least 5 years , 3) managers, the population is 5 people, the finance manager, marketing, production, HR and general manager, 4) staff, the population is 5 people, who work in that section.

\section{Data Analysis Methods}

For ease of analysis, the identification and grouping variables in advance based on the research problem. Grouping variable is done in two parts, ie variable that describes (exogenous) and the variables that explained (endogenous). Variables that explain the (independent variable) is the external environment and internal environment, while the planning and management of human resources, employee improvement, education and training, and employee databases must address satisfying recognition and employee satisfaction as an intervening variable and human capital as a variable that explained (endogenous / bound).

To test the hypothesis of this study, the variables are defined in advance, and then translated into operational definitions. This is done for each of the variables and indicators of research is clearly measurement scale. The variables used in this study, both the independent variable (exogenous) and the dependent variable (endogenous) can be explained as follows:

1. Independent variables (exogenous) given symbol $\mathrm{X}$, the variables identified and suspected as a cause that affects the dependent variable (endogenous), the external environment (X1) and internal environment (X2).

2. Endogenous variables (intervening) given symbol Y1-5, which is a variable which is among of the independent variables to determine which is the dependent variable from the independent variable affected variables, planning and human resource management, employee improvement, education and training, employee performance and recognition, employee satisfaction .

3. Endogenous variables given the symbol Y6, which is a variable that is affected by variables of the independent variables (exogenous) and intervening variables. This variable is the development of human capital. The method of analysis used in this study is the model equation Structural Equation Modeling (SEM) to determine the causal relationship between latent variables contained in the structural equation. While analysis 
tools are used is essential to the simultaneous regression with the reduced form framework of analysis is shown in Figure 2 below.

\section{A. Results}

\section{Results And Discussion}

Validity test is done to see which items are worthy questions (representative) is used to represent the independent variables in this study. This test is done by using confirmatory factor analysis (confirmatori factor analysis) on each of the latent variables using AMOS 7.0 program. If the value of the indicator loading factor greater than 0.5, the indicator can be used to measure the variables (Chin, in Ghozali, 2005).

Test validity was not emphasized in the study compared with the quantitative and qualitative research is more important is the reliability test (Susan, 1998) in Sugiyono (2008). Furthermore if r-count is greater than r-table at a certain confidence level, meaning that it meets the criteria for the validity of the instrument. Confidence level used Dalan validity test items in this study was $95 \%$ with the number of respondents $120(\mathrm{~N}=120)$. Items that have a count value of $r>r$ table (0.196) the items used in the study. Baumgartner and Homburg (1996), and Hershberger (2003) said that the linear model is not significant if it is below $(\mathrm{t}=0.850, \mathrm{p}=0.41)$ that develops in a linear SEM.

Reliability test, which is an index that indicates the extent to which reliable measuring instrument or trustworthy. Reliability is a measure of internal consistency of the indicators showed a konsruk the degree to which each indicator variable that identifies a formation or a common latent factor. Reliability in this study was calculated using a composite (construct) reliability with a minimum cut-off value of 0.6 (Maholtra, in Solimun, 2002). The calculation is as follows:

$$
\text { Construct Reliability }=\frac{\left(\sum \text { Standardized Loading }\right)^{2}}{\left.\left(\sum \text { Standardized Loading }\right)^{2}+\sum \mathrm{e}_{\mathrm{j}}\right)}
$$

Where: Standard Loading obtained directly from the standardized loading for each indicator the lambda values generated by each of the indicators. $e_{-} j$ is the measurement error of each indicator. Measurement error is equal to 1 - reliability indicator of the squared standardized loading of each indicator is analyzed. Limit values are used to assess an acceptable level of reliability is 0.60 (Maholtra, in Solimun, 2002: 71). When the research is the explanatory value below 0.60 was still acceptable along with the empirical reasons. After the match the model and the data as a whole is good, the next step is an evaluation or test the research model fit. Evaluation was conducted on each construct or measurement model (relationships between a latent variable with some unobserved variables separately via: 1) Evaluation of validity (validity) of the research model, and 2) evaluation of the reliability (reliability) of the research model.

Construk reliability of the calculations and the estimated value of the external environment variable values obtained CR estimates of 0.729 and above 0.7 . This value indicates that the fourth is reliable and valid indicators to form the external environment variables. To the researchers decided to retain the four variables and indicators in the research model. Internal environment variable CR values obtained above estimates of 0.904 and 0.7. This value indicates that reliable and valid indicators to measure latent vaiabel. To the researchers decided to retain three variables and indicators in the research model.

Construk reliability of the calculations and the estimated value of the variable HR planning and management of CR values obtained at 0,703 and estimated above 0.7 . This value indicates that all three of these indicators are reliable and valid to measure latent variables. To the researchers decided to retain three variables and indicators in the research model. To increase employee variables obtained CR value of 0.723 and the estimates above 0.7. This value indicates that the fourth is reliable and valid indicators to measure latent variables. To the researchers decided to retain the four variables and indicators in the research model.

Construk reliability of calculation and estimation of the variable value of education and training obtained CR values of 0.788 and 0.7 above estimates. This value indicates that reliable and valid indicators to measure latent variables. To the researchers decided to retain the four variables and indicators in the research model. To variable employee performance and recognition obtained CR value of 0.815 and the estimates above 0.7 . This value indicates that the fourth is reliable and valid indicators to measure latent variables. To the researchers decided to maintain and indicator variables in the model.

Construk reliability of the calculations and the estimated value of the variable employee satisfaction obtained CR values of 0.721 and 0.7 above estimates. This value indicates that reliable and valid indicators to measure latent variables. To the researchers decided to maintain the variables and indicators in the research model. To the human capital variables obtained CR value of 0.742 and the estimates above 0.7 . This value indicates that reliable and valid indicators to measure latent variables. To the researchers decided to maintain the variables and indicators in the research model. 


\section{Analysis of Structural Equation Model(SEM)}

Having tested the validity and reliability of all latent variables are valid and reliable results, the latent variable can be proceed with testing the suitability of the model and the significance test causality.

\section{a. Model Conformance Test (Goodness-of-fit test)}

The results of testing the suitability of the model as a whole in this study are presented in table 1 .

Tabel 1.Uji kesesuaian seluruh model(Goodness-of-fit test)

\begin{tabular}{|l|l|l|l|}
\hline Kiteria & Cut-off & Hasil & Evaluasi \\
\hline Chi-Square & Diharapkan kecil & 0.0187 & Baik \\
\hline Probability & $\geq 0.05$ & 0.072 & Baik \\
\hline RMSEA & $\leq 0.06$ & 0.057 & Baik \\
\hline TLI & $\geq 0.95$ & 0.971 & Baik \\
\hline CFI & $\geq 0.80$ & 0.886 & Baik \\
\hline CMIN/DF & $\leq 2.00$ & 0.000 & Baik \\
\hline \multicolumn{4}{|l}{ Source: Data processed (AMOS 7.0 output) }
\end{tabular}

Table 1 shows all the criteria used to determine the appropriateness of a model have been met, and does not need to be modified. It is clear that the model can be accepted or there is a match between the model and the data.

The external environment spesific test models based on Table 2 shows the six criteria used decent, good and fulfilled, and does not need to be modified. It is clear that the model can be accepted or the suitability.

Table 2. Spesific test External Environment Model (X1)

\begin{tabular}{|l|l|l|l|}
\hline Kiteria & Cut-off & Hasil & Evaluasi \\
\hline Chi-Square & Diharapkan kecil & 0.0187 & Baik \\
\hline Probability & $\geq 0.05$ & 0.072 & Baik \\
\hline RMSEA & $\leq 0.06$ & 0.047 & Baik \\
\hline TLI & $\geq 0.95$ & 0.972 & Baik \\
\hline CFI & $\geq 0.80$ & 0.816 & Baik \\
\hline CMIN/DF & $\leq 2.00$ & 0.0002 & Baik \\
\hline \multicolumn{4}{|c|}{ Source: Data processed (AMOS 7.0 output) }
\end{tabular}

Based on Table 3 Test Environment spesific internal model shows six criteria used to determine whether or not a model, already well and fulfilled, and does not need to be modified. It is clear that the model can be accepted or there is a match between the model and the data.

Table 3. Internal Environment Model spesific test (X2)

\begin{tabular}{|l|l|l|l|}
\hline Kiteria & Cut-off & Hasil & Evaluasi \\
\hline Chi-Square & Diharapkan kecil & 0.0016 & Baik \\
\hline Probability & $\geq 0.05$ & 0.061 & Baik \\
\hline RMSEA & $\leq 0.06$ & 0.056 & Baik \\
\hline TLI & $\geq 0.95$ & 0.988 & Baik \\
\hline CFI & $\geq 0.80$ & 0.811 & Baik \\
\hline \multicolumn{1}{|c|}{ CMIN/DF } & $\leq 2.00$ & 0.0032 & Baik \\
\hline
\end{tabular}

Source: Data processed (AMOS 7.0 output)

Tables 4 based on spesific Test Model HR planning and management of the six criteria used to determine whether or not a model, have been met, and does not need to be modified. It is clear that the model can be accepted or there is a match between the model and the data.

Table 4. Test specific HRP and M Model (Y1)

\begin{tabular}{|l|l|l|l|}
\hline Kiteria & Cut-off & Hasil & Evaluasi \\
\hline Chi-Square & Diharapkan kecil & 0.0231 & Baik \\
\hline Probability & $\geq 0.05$ & 0.000 & Baik \\
\hline RMSEA & $\leq 0.06$ & 0.046 & Baik \\
\hline TLI & $\geq 0.95$ & 0.971 & Baik \\
\hline CFI & $\geq 0.80$ & 0.835 & Baik \\
\hline CMIN/DF & $\leq 2.00$ & 0.1155 & Baik \\
\hline
\end{tabular}

Source: Data processed (AMOS 7.0 output) 
Table 5 shows the six criteria used to determine whether or not a model, have been met, and does not need to be modified. It is clear that the model can be accepted or there is a match between the model and the data.

Table 5. Increased Employee spesific test model (Y2)

\begin{tabular}{|l|l|l|l|}
\hline Kiteria & Cut-off & Hasil & Evaluasi \\
\hline Chi-Square & Diharapkan kecil & 0.0011 & Baik \\
\hline Probability & $\geq 0.05$ & 0.090 & Baik \\
\hline RMSEA & $\leq 0.06$ & 0.056 & Baik \\
\hline TLI & $\geq 0.95$ & 0.091 & Baik \\
\hline CFI & $\geq 0.80$ & 0.087 & Baik \\
\hline CMIN/DF & $\leq 2.00$ & 0.0055 & Baik \\
\hline
\end{tabular}

Source: Data processed (AMOS 7.0 output)

Table 6 shows the six criteria used to determine whether or not a model, have been met, and does not need to be modified. It is clear that the model can be accepted or there is a match between the model and the data.

Table 6. Test Model spesific Education and Training (Y3)

\begin{tabular}{|l|l|l|l|}
\hline Kiteria & Cut-off & Hasil & Evaluasi \\
\hline Chi-Square & Diharapkan kecil & 0.0285 & Baik \\
\hline Probability & $\geq 0.05$ & 0.236 & Baik \\
\hline RMSEA & $\leq 0.06$ & 0.047 & Baik \\
\hline TLI & $\geq 0.95$ & 0.987 & Baik \\
\hline CFI & $\geq 0.80$ & 0.996 & Baik \\
\hline CMIN/DF & $\leq 2.00$ & 0.00143 & Baik \\
\hline
\end{tabular}

Source: Data processed (AMOS 7.0 output)

Table 7 shows the six criteria used to determine whether or not a model, have been met, and does not need to be modified. It is clear that the model can be accepted or there is a match between the model and the data.

Table 7. Test spesific Model Employee Performance and Recognition (Y4)

\begin{tabular}{|l|l|l|l|}
\hline Kiteria & Cut-off & Hasil & Evaluasi \\
\hline Chi-Square & Diharapkan kecil & 0.0285 & Baik \\
\hline Probability & $\geq 0.05$ & 0.236 & Baik \\
\hline RMSEA & $\leq 0.06$ & 0.047 & Baik \\
\hline TLI & $\geq 0.95$ & 0.987 & Baik \\
\hline CFI & $\geq 0.80$ & 0.996 & Baik \\
\hline CMIN/DF & $\leq 2.00$ & 0.00143 & Baik
\end{tabular}

Source: Data processed (AMOS 7.0 output)

Based on Table 8 on Employee Satisfaction Model spesific test showed six criteria used to determine whether or not a model, have been met, and does not need to be modified. It is clear that the model can be accepted or there is a match between the model and the data.

Table 8. Employee Satisfaction spesific test model (Y5)

\begin{tabular}{|l|l|l|l|}
\hline Kiteria & Cut-off & Hasil & Evaluasi \\
\hline Chi-Square & Diharapkan kecil & 0.002 & Baik \\
\hline Probability & $\geq 0.05$ & 0.007 & Baik \\
\hline RMSEA & $\leq 0.06$ & 0.047 & Baik \\
\hline TLI & $\geq 0.95$ & 0.972 & Baik \\
\hline CFI & $\geq 0.80$ & 0.821 & Baik \\
\hline CMIN/DF & $\leq 2.00$ & 0.001 & Baik \\
\hline
\end{tabular}

Source: Data processed (AMOS 7.0 output)

Table 9 shows the six criteria used to determine whether or not a model, have been met, and does not need to be modified. It is clear that the model can be accepted or there is a match between the model and the data.

Table 9. Test spesific human capital model (Y6)

\begin{tabular}{|l|l|l|l|}
\hline Kiteria & Cut-off & Hasil & Evaluasi \\
\hline Chi-Square & Diharapkan kecil & 0.057 & Baik \\
\hline Probability & $\geq 0.05$ & 0.057 & Baik \\
\hline RMSEA & $\leq 0.06$ & 0.058 & Baik \\
\hline TLI & $\geq 0.95$ & 0.972 & Baik \\
\hline CFI & $\geq 0.80$ & 0.821 & Baik \\
\hline CMIN/DF & $\leq 2.00$ & 0.0085 & Baik \\
\hline
\end{tabular}

Source: Data processed (AMOS 7.0 output) 


\section{b. Causality Relationships Between Variables}

After testing the suitability of the models in this study, the next step is to test causality hypothesis. In the following table are shown the significance of the marked influence of variables on the probability value when under $\mathrm{P} \leq 5 \%$ or beyond the limits of \pm 1.96 in the significant two-way test, whereas if they are in the area then there siginikan \pm 1.96 (Sugiyono, 2008).

Interpretation of the data of each path coefficient output by AMOS 7.0 are as follows:

1.One Hypothesis (H1): The external environment influence the planning and human resources management. AMOS software show that the calculation results that the external environment (X1) positive and significant impact on the planning and management of human resources (Y1). This is evident from the marked positive path coefficient of 0.781 with a value of CR amounted to 3,339 and obtained a significant probability of 0.000 . This probability value is smaller than the significance level $(\alpha)$ set at 0.05 , thus $\mathrm{H1}$ is accepted.

2. Two Hypothesis (H2): The internal environment influence the planning and human resource managemenet. The calculations show that the internal environment (X2) positive and significant impact on human resource management (Y1). This is evident from the marked positive path coefficient of 0.851 with a value of CR amounted to 4,343 and obtained a significant probability of 0.000 . This probability value is smaller than the significance level $(\alpha)$ defined by 0.05 , thus $\mathrm{H} 2$ is accepted.

3. Three Hypothesis (H3): The external environment influence the increased employee.

The calculation results that the external environment (X1) and no significant positive effect on increasing employee (Y2). This is evident from the marked positive path coefficient of 0.452 with a value of CR of 0373 and obtained a significant probability of 0.056 . This probability value is greater than the significance level $(\alpha)$ defined by 0.05 , thus $\mathrm{H} 3$ is rejected.

4. Four Hypothesis (H4): The internal environment influence on the increased employee.

The calculations show that the Internal Environment (X2) and a significant positive effect on increasing employee (Y2). This is evident from the marked positive path coefficient of 0.715 with a value of CR amounted to 5,723 and obtained a significant probability of 0.000 . This probability value is smaller than the significance level $(\alpha)$ defined by 0.05 , thus $\mathrm{H} 4$ is accepted / proven.

5. Five Hypothesis (H5): The external environment influence on education and training.

The calculations show that the external environment (X1) positive and significant impact on education and training (Y3). This is evident from the marked positive path coefficient of 0.978 with a value of CR amounted to 4,040 and obtained a significant probability of 0.000 . This probability value is smaller than the significance level $(\alpha)$ defined by 0.05 , thus $\mathrm{H} 5$ is accepted.

6. Six Hypothesis (H6): The interna environment influence on education and training.

The calculations show that the internal environment (X2) positive and significant impact on education and training (Y3). This is evident from the marked positive path coefficient of 0.725 with a value of CR amounted to 2,597 and obtained a significant probability of 0.015 . This probability value is smaller than the significance level $(\alpha)$ defined by 0.05 , thus $\mathrm{H} 6$ is accepted.

7. Seven Hypothesis (H7): The external environment Influence on employee performance and recogniting.

The calculations show that the external environment (X1) and no significant positive effect on employee performance and recognition (Y4). This is evident from the marked positive path coefficient of 0.221 with a value of CR amounted to 1,077 and obtained a significant probability of 0.052 . This probability value is greater than the significance level $(\alpha)$ defined by 0.05 , thus $\mathrm{H} 7$ is rejected.

8. Eight Hypothesis (H8): The internal environment Influence on employee performance and recognition.

The calculations show that the internal environment (X2) and a significant positive effect on employee performance and recognition (Y4). This is evident from the marked positive path coefficient of 0.718 with a value of CR amounted to 3,373 and obtained a significant probability of 0.000 . This probability value is smaller than the significance level $(\alpha)$ defined by 0.05 , thus $\mathrm{H} 8$ is received.

9. Nine Hypothesis (H9): The external environment influence on satisfaction employee.

The calculations show that the external environment (X1) and no significant positive effect on employee satisfaction (Y5). This is evident from the marked positive path coefficient of 0.346 with a value of CR obtained at 0.260 and significant probability of 0.061 . This probability value is greater than the significance level $(\alpha)$ defined by 0.05 , thus $\mathrm{H} 9$ is rejected.

10. Ten Hypothesis (H10): Internal Environmental influence on satisfaction Employee.

The calculations show that the internal environment (X2) and a significant positive effect on employee satisfaction (Y5). This is evident from the marked positive path coefficient of 0.914 with a value of CR 
amounted to 4,969 and obtained a significant probability of 0.000 . This probability value is smaller than the significance level $(\alpha)$ defined by 0.05 , thus H10 is accepted.

11. Eleven Hypothesis (H11): The external environment Influence on the human capital development.

The calculations show that the external environment (X1) and a significant positive effect on the development of human capital (Y6). This is evident from the marked positive path coefficient of 0.922 with a value of CR of 4697 and obtained a significant probability of 0.000 . This probability value is smaller than the significance level $(\alpha)$ defined by 0.05 , thus $\mathrm{H} 11$ is accepted.

12. Twelve Hypothesis (H12): The internal environment Influence on the human capital development.

The calculations show that the internal environment (X2) and a significant positive effect on the development of human capital (Y6). This is evident from the marked positive path coefficient of 0.831 with a value of CR amounted to 3,582 and obtained a significant probability of 0.000 . This probability value is smaller than the significance level $(\alpha)$ defined by 0.05 , thus H12 is accepted.

13. Thirteen Hypothesis (H13): Planning and management of human resources influence on human capital development.

The calculations show that the planning and management of human resources (Y1) and a significant positive effect on the development of human capital (Y6). This is evident from the marked positive path coefficient of 0.978 with a value of CR amounted to 4,040, obtained a significant probability of 0.000 . This probability value is smaller than the significance level $(\alpha)$ set at 0.05 , thus H13 is accepted.

14. Fourteen Hypothesis (H14): Increased employee influence human capital development

The calculations show that the increase in employees (Y2) and a significant positive effect on the development of human capital (Y6). This is evident from the marked positive path coefficient of 0.713 with a value of CR amounted to 3,182 and obtained a significant probability of 0.000 . This probability value is smaller than the significance level $(\alpha)$ set at 0.05 , thus H14 is accepted.

15. Fifteen Hypothesis (H15): Education and training affect the human capital development. The calculations show that education and training (Y3) and a significant positive effect on the development of human capital (Y6). This is evident from the marked positive path coefficient of 0.757 with a value of CR amounted to 3,348 and obtained a significant probability of 0.000 . This probability value is smaller than the significance level $(\alpha)$ set at 0.05 , thus H15 is accepted.

16. Sixteen Hypothesis (H16): Employee performance and recognition of influence human capital development.

The calculations show that the performance of employees and recognition (Y4) and a significant positive effect on the development of human capital (Y6). This is evident from the marked positive path coefficient of 0.721 with a value of CR amounted to 3,384 and obtained a significant probability of 0.000 . This probability value is smaller than the significance level $(\alpha)$ set at 0.05 , thus H16 is accepted.

17. Seventeen hypothesis (H17): effect on the development of employee satisfaction human capital development

The calculations show that employee satisfaction (Y5) and a significant positive effect on the development of human capital (Y6). This is evident from the marked positive path coefficient of 0.721 with a value of CR amounted to 2,520 and obtained a significant probability of 0.012 . This probability value is smaller than the significance level $(\alpha)$ set at 0.05 , thus $\mathrm{H} 17$ is accepted.

Based on the results of testing the hypothesized relationship between the variables of the relationship between, it can be further illustrated in Figure 12 below.

Figure 2. Pattern Scheme Results Through Relationships Between Variables SEM Analysis 


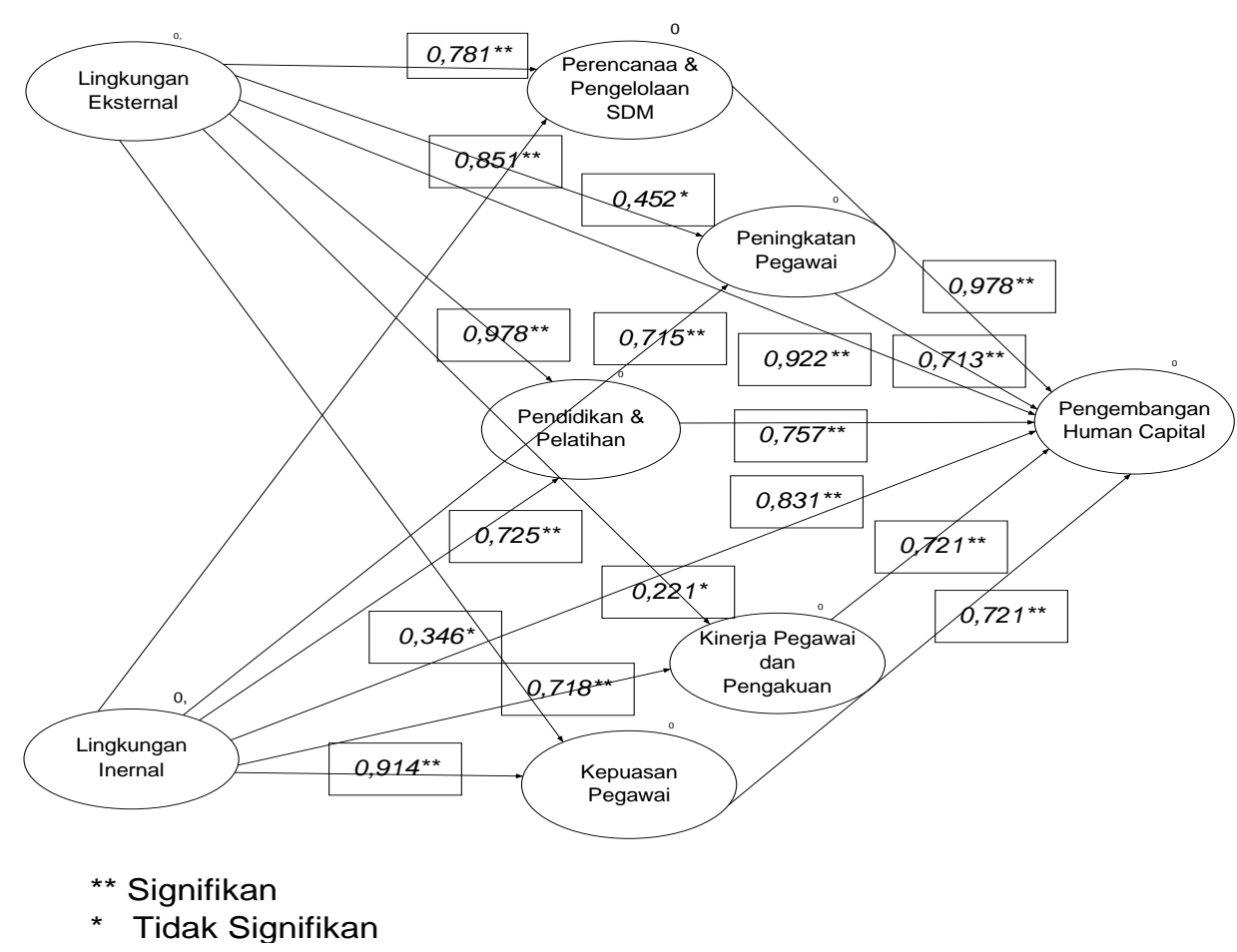

\section{Influence Between Variables}

Total effect is the overall effect of direct and indirect influence between the variables in the model. The goal is to see the magnitude of a direct relationship between the variables and after going through the intervening variable, and according to Ferdinand (2002) that the total effect is added between the direct and indirect effects. Based on the calculation and analysis, the total effect of the external environment and internal environment, the planning and management of human resources, employee improvement, education and training, employee performance and recognition, employee satisfaction, and the development of human capital is described as follows:

1. The influence of the external environment (X1) significantly to the planning and management of human resources (Y1) 0.781, education and training (Y3) 0.978, and the development of human capital (Y6) 0.922, it shows the strong influence of the external environment on some endogenous variables, but weakened in increased employee (Y2) 0452, employee performance and recognition (Y4) 0.221 , and employee satisfaction (Y5) of 0.346.

2. Internal environmental influences (X2) significantly to the planning and management of human resources (Y1) 0.851, increased employee (Y2) 0715, education and training (Y3) 0725, employee performance and recognition (Y4) of 0718, employee satisfaction (Y5) 0.914, and human capital development (Y6) 0831, it shows the strong influence of the external environment on the endogenous variables.

3. Influence the planning and management of human resources (Y1) is significant to the development of human capital (Y6) 0.978, it shows the strong influence of human resource management and planning (Y1) to human capital.

4. Effect of increased employee (Y2) significantly to the development of human capital (Y6) sebesr 0.713, it shows the strong influence of increased employee (Y2) to the development of Human Capital.

5. The influence of education and training (Y3) significantly to the development of human capital (Y6) 0.757, it shows the strong influence of education and training (Y3) to the development of human capital.

6. Influence employee performance and recognition (Y4) significantly to the development of human capital (Y6) 0.721 , it shows the strong influence employee performance and recognition (Y4) to the development of human capital.

7. Influence employee satisfaction (Y5) significantly to the development of human capital (Y6) 0.721, it shows the strong influence of employee satisfaction (Y5) towards the development of human capital.

\section{Discussion}

Based on the analysis of the results of research that has been described earlier, the following discussion is done to prove the hypothesis. Discussion conducted by decrypt strong influence of exogenous variables on 
endogenous vaiabel and the goal variables (human capital). Description strong influence among variables and then compared with the empirical evidence gathered in the field, and the theories that support the hypothesis. The following discussion is based on the path phase relationship between the variables in the model:

\section{External environmental influences on human resource planning and management}

External environment positive and significant impact on human resource planning and management. The study's findings are in line with studies Davenport (1999), Baldridge (2001), Oudenhoven (2000), Baldridge (2001), Saputra (2005), and Waromi (2006) that the strengthening of human resource planning and management are always adapted to changes in the external environment, which changes in the external environment according to Hill (1998) occurs on changing political and legal environment, economic, technological, demographic, and social environments. More than that, employees of manufacturing companies going public is much related to the technical condition of the stock exchanges such as economic conditions, and the workings of the technology as the company seeks to maintain the market price of the stock to investors and prospective investors, so the quality of the knowledge and skills of existing employees are always improved every environmental changes in order to increase the company's profitability. Robust economic change, socio-cultural, technological, political / legal and demographic according to Hitt and Ireland (1997) will strengthen the planning and management of human resources of manufacturing firms going public.

Empirical conditions that occur in planning and human resource management at manufacturing companies going public, always pay attention to changes in economic, social, cultural, technological, political / legal and demographic, not just related to changing tastes and market demand, but associated with increased flexibility and competence and productivity employees to meet the company's work program which is influenced by changes in the external environment. Implications of these findings for human resource managers of manufacturing firms going public is that planning and human resource management needs to be improved by changing the external environmental conditions such as changes in economic conditions, socio-cultural, technological, political/legal and demographic.

\section{Internal environmental influences on human resource planning and management}

Internal environment positive and significant impact on human resource planning and management. The study's findings are in line with research Oudenhoven (2000), and Baldridge (2001) that in order to build a human resource planning and management should strengthen the internal environment.

Empirical conditions that occur in planning and human resource management at manufacturing companies going public, always pay attention to working conditions, monotonous environments make employees bored and less motivated to work and be creative. Indicators of environmental change in the internal resources, capabilities, and core competencies is often done as a means of additional work, arrangement of the room and the addition of working equipment, introducing a more modern work tools quickly and accurately, the creation of internal discussions membimbingan employees to develop competencies and technical skills appropriate the job run. Implications of these findings for human resource managers of manufacturing firms going public is that planning and human resource management needs to be improved by changing the internal environmental conditions such as the availability of facilities and work adjustment skills and competencies of employees with jobs that are run, and the creation of working environment motivates employee productivity.

\section{The influence of the external environment to increase employee}

External environment and no significant positive effect on employee improvement. This finding is consistent with research Sanjoyo (2004), and Baldridge (2001) that an increase in the quality of employees are not affected by the external environment, because the external environment does not establish employee proficiency and quality, and frequency of changes in the external environment for manufacturing companies that go public just be- tentative on the market price of the stock. While these findings are not consistent with the results of Herzberg (1997), Furnharn (1991), and Bambrough (1998) that an increase in the quality of employees is an adjustment of employee skills and technological changes that the new working methods.

Empirical conditions that occur on increasing employees at manufacturing companies go public, do not always pay attention to changes in the external environment. Changes in external conditions such as changes in customer tastes, behavior of competitors, availability of labor and skills, and the condition change is tentative and macro level. If the four components are likely to affect product demand, and significant management can then ask the employee to improve its capacity and improve its capabilities to make changes in the product that gives the product differentiation that adapts to market demand, such as sending employees overseas to perform benchmarking.

Implications of these findings for human resource managers manufacturing companies going public. Employee quality can be improved by performing technical guidance or by benchmarking if market demand products manufacturing industry significantly affected by changes in the external environment. 
4. Influence of the internal environment increase employee

Internal environment and a significant positive effect on employee improvement. This research was appropriate and consistent with the research Moskowits and Warwick (1996), Daft (2006), and Kiker (1996) that an increase in the quality of employees can be increased in line with increased resources, infrastructure work, and working conditions.

Empirical conditions that occur on increasing employees at manufacturing companies that go-public, always to improve the quality of resources, capabilities and core competencies to perform guidance, education, and job training along with the addition of working facilities, arrangement of the room and the addition of work equipment, introduces modern working tools more quickly and precisely, create harmonization of the internal relations of fellow workers. Implications of these findings for human resource managers of manufacturing companies go public-employee is that the increase in quality can be improved by improving the internal environment, such as the preparation of working facilities for their intended purpose and adjustment with the skills and competencies of employees whose jobs are run, and to create an atmosphere of working which gives the motivation and productivity of employees.

\section{The influence of the external environment to education and training}

External environment positive and significant impact on education and training. This finding is consistent with research Baldrige (2001), and Zee (2000) that the knowledge and skills of employees can be improved through education and training, while education and training as well as technical guidance field can be done if the external environment changes, such as changes in technology, changes in market information, and changes in market behavior.

Empirical conditions that occurred in the education and training of employees in manufacturing companies going public, always adapt to the development trend of technology, industry, and market. The main objectives of education and training to employees is to improve the quality of the resources, capabilities, and competencies. Educational methods are implemented always tailored to the information technology, meode production, marketing and the latest technology. Training materials on increasing mastery of theory and decision-making skills. Implications of these findings for human resource managers of manufacturing companies going public, that education and training are run more directed at employees flexibility to the changing external environment. Flexibility is the sensitivity and change employee behavior to environmental changes.

\section{Internal environmental influences on education and training}

Internal environment positive and significant impact on education and training. The study's findings are in line with research Honig (1998), and Peter et al (1996) that the education and training of employees are determined by the internal condition of the company, in this case is the management company.

Empirical conditions that occurred in the education and training of employees in manufacturing companies going public, always adjusting to the needs of management. The main objectives of education and training to employees is to improve the quality of the resources, capabilities, competencies, and corporate culture. Education and training carried out at any time if needed management changes and increased keterampilan.Implikasi these findings for HR managers of manufacturing firms going public is that the education and training of human resources is always implemented changes aimed to suit the needs of the manufacturing enterprise management.

\section{External environmental influences on employee performance and recognition}

External environment and no significant positive effect on employee performance and recognition. The study's findings are in line with research Baldrige (2001), Donnelly (1994), Rival (2005), and Sutermeister (1999), and not in line with the results of Metz (2003), Child (1997), and Lee and Miller (1996) , because the external environment has not motivate employee productivity, in addition to the management of manufacturing companies going public are still holding on to the company's initial strategy, and survived until the price changes in the stock market is bullish or bearish

Empirical conditions that occur on employee performance and recognition in the event of changes in the external environment-manufacturing companies that go public, do not automatically have an impact, because due to the external environment has not motivate employee productivity, in addition to the management of manufacturing companies going public are still adhering to the company's initial strategy, and attention to changes in the external environment as well as the duration of the behavior of investors in the capital market, are likely to take profit (profit taking) is only tentative, or share price condition is corrected. Only the external environment impact on the macro-management of the company, while the microeconomic performance of employees, ie the productivity of employees based management strategies executed, meaning if there is a change of external environment, the management company just needs to make adjustments to the strategy, including the strengthening of human resource strategy. Implications of these findings for human resource 
managers of manufacturing firms going public is that employee performance and recognition of human resources remain employed despite the changing conditions improved external environment on the economic, social, cultural, technological, political and demographic.

\section{Internal environmental influences on employee performance and recognition}

Internal environment and a significant positive effect on employee performance and recognition. The study's findings are in line with research Baldrige (2001), Donnelly (1994), Daft (2006), Hasibuan (2001), Rival (2005), Sutermeister (1999), and Metz (2003) that the employee performance and recognition is largely determined by the environment Internal company, in this case is the application of human resource management within

the

company.

Empirical conditions that occur on employee performance and recognition in manufacturing companies going public, always adjust the performance indicators set by the management. The main objective performance appraisal in manufacturing companies go public is to increase motivation, change and improvement of the skills that support the industry and market conditions, primarily seeks to maintain the company's reputation in the capital markets. Implications of these findings for human resource managers of manufacturing firms going public is that employee performance and recognition of human resource management continuously monitored in order to motivate and support the achievement of management's reputation in the capital markets.

\section{External environmental influences on employee satisfaction}

External environment and no significant positive effect on employee satisfaction. The study's findings are in line with research Yurniwati (2003), Anwar (2009), Monson (2000), Sugiyanto (2007), and Waromi (2006) that employee satisfaction is not determined by the external environment. While the findings of this study presented significant not only because the external environment is the macro information and indirect benefits to the needs and desires of employees, temporary employees kepusan related to the utility of the compensation and working facilities are obtained, as well as meeting the needs of employees who obtained after providing labor services to companies

Empirical conditions that occur on the satisfaction of employees in the event of changes in the external environment of manufacturing firms going public is not there, because the external environment and the macro informational only indirect benefits and the achievement of utilities, employee needs and desires. On the other hand that the change in external conditions not be the critical area for employees to work and act. Implications of these findings for human resource managers of manufacturing firms going public is that the job satisfaction of employees needs to be improved despite the changing external environment, such as still meeting the needs of employees, preparing the means of work, and ask partisasi employees working in management.

\section{Internal environmental influences on employee satisfaction}

Internal environment and a significant positive effect on employee satisfaction (Y5). Findings of this study is in line with research Metz (2003), Sitanggang (2009), Robbins (2006), DFAT (2006), Monson (2000), and Baldridge (2001) that internal environments such as corporate strategy, organizational structure, culture, management, marketing, information systems, and control systems, and physical resources affect employee satisfaction. If the company can optimize the use of resources so all stakeholders, including the employees will feel satisfied.

Empirical conditions that occur on the satisfaction of employees in manufacturing firms going public, only related to the fulfillment of expectations and needs are balanced with the work that has been carried out. Job satisfaction of employees in manufacturing companies go public is to be seen of his motivation, as well as the interaction between leaders and subordinates, as well as interactions among employees daklam our team. Implications of these findings for human resource managers of manufacturing firms going public is that the job satisfaction of employees need to be increased to maintain the internal environment, such as the need for employees, setting up means of work, and ask partisasi employees working in management.

\section{External environmental influences on the development of human capital}

External environment and a significant positive effect on the development of human capital. The study's findings are in line with research Martina, Antonius and Rachmawati (2007), Wyatt (1995) that the development of human capital is determined by the external environment. Manufacturing firms going public is always oriented to adjust to economic conditions and market conditions experienced development trend, including the trend of development of competence and skills of employees, as human capital that can support the development of the company to retain its market value in the capital market.

Empirical conditions that occur in the development of human capital in manufacturing companies going public, is largely determined by changes in the external environment, as some investors from overseas parent company prefers to apply his management to synchronize between parent and child management company in case of problems in the economy and changes technology. Implications of these findings for human 
resource managers of manufacturing firms going public is that the development of human capital needs to be improved by changing the external environmental conditions such as changes in economic conditions, sociocultural, technological, political/legal and demographic.

\section{Internal environmental influences on the development of human capital}

Internal environment positive and significant impact on the development of human capital. The study's findings are in line with research Martina, Antonius and Rachmawati (2007), Sugiyanto (2007), Sugiyanto (2007), Covey (1990), Moskowits and Warwick (1996), that the development of human capital can be done through strengthening the internal environment, such as the ability , increased knowledge, improved skills, and managerial skills in taking decisions. More than that, the strengthening of the internal environment is done in the formulation of corporate strategy, systems and work procedures, information systems, and control systems.

Empirical conditions that occur in the development of human capital in a manufacturing company gopublic, is largely determined by the internal environment support, which the company continues to work to improve management of employee competence and managerial skills. Besides, the company's management to formulate corporate strategy with emphasis on increasing skills and knowledge of employees. Implications of these findings for human resource managers of manufacturing firms going public is that the development of human capital needs to be improved with strong management support contained in the formulation of human resource development strategy.

\section{Influence the planning and management of human resources to the development of human capital.}

Planning and management of human resources and a significant positive effect on the development of human capital. The study's findings are in line with research Saputra (2005), Cressy (1999), Kiker (1996), Monson (2000), Honig (1998), Wayne (1999), and Syahrial (2004), that the development of human capital can be done by development planning and human resource management. According to Mathis and Jackson (2001), that the problems associated with the organization's human resources, related to workforce needs, training and deploying personnel who are ready, promotion and demotion of office, manage the entire workforce or welfare of employees and others.

Empirical conditions that occur in the development of human capital in manufacturing companies going public, is largely determined by the support of the planning and management of human resources in manufacturing companies going public, ranging from planning needs of employees, promotion, education and training, payroll, bonus determination of work, and retirement planning. Implications of these findings for human resource managers of manufacturing firms going public is that the development of improved human capital ranging from recruitment, job placement, education and training, and compensation.

\section{The effect of the increase in employee on the development of human capital.}

Increased employee positive and significant impact on the development of human capital. The study's findings are in line with research Naibaho (2006), Rival (2009), Fitz-ent (2000), Sugiyanto (2007) that the development of human capital (human capital) is determined by an increase in personnel. Increased employee by Rival (2009), the company needs both short term, medium and long term, because the needs and skill levels of employees need to be planned, then the process of technology transfer among employees who have reached retirement age with an employee who started his career in a system arranged employment or job description.

Empirical conditions that occur in the development of human capital in manufacturing companies going public, is always to improve the quality of resources, capabilities and core competencies to perform guidance, education, and job training are set out in the business strategy. Implications of these findings for human resource managers of manufacturing firms going public is that the development of human capital should be increased with an increase in employee selection, job placement, education, and job training are set out in the business strategy.

15. The influence of education and training to the development of human capital

Education and training, and a significant positive effect on the development of human capital. The study's findings are in line with research Kiker (1996), Monson (2000), Syahrial (2004), and Sugiyanto (2007) that human capital development is influenced by education and training. Education and training expected to produce a change in knowledge and behavior. Thus, education and training to help structuring behavior and improve cognitive abilities, affective, and psychomotor.

Empirical conditions that occur in the development of human capital in manufacturing companies going public, is always to improve the quality of resources, capabilities and core competencies to perform technical guidance, education, and job training are programmed based on need. Implications of these findings for human resource managers of manufacturing firms going public is that the development of human capital can be increased through education and training, help organize employee behavior, enhance cognitive abilities, affective, and psychomotor. 
16. Influence employee performance and recognition the development of human capital

Employee performance and recognition of positive and significant impact on the development of human capital. This finding is consistent with research Monson (2000), Idayanti (2003), Nurmala (2006), Sugiyanto (2007) that the development of human capital can be done by increasing sustainable productivity. Relationship between human capital and performance very closely, because not all employees have a value which is seen as capital. Employees who have the skills and knowledge that is not considered a low-capital, because it has no sale value, while employees are skilled and knowledgeable human capital can be said to be because it was able to show continuous performance.

Empirical conditions that occur in the development of human capital in manufacturing companies going public, is to conduct monitoring and evaluation of employee achievement. Employees who have highperformance continuous then promoted to higher positions. The goal is to be able to motivate others to improve their knowledge and skills. Implications of these findings for human resource managers of manufacturing firms going public is that the development of human capital can be increased through monitoring and evaluation of employee performance on an ongoing basis.

\section{Influence employee satisfaction towards the development of human capital}

Employee satisfaction and significant positive effect on the development of human capital. This finding is consistent with research Purba (2008), Metz (2003), Sugiyanto (2007), Zee (2000), Cooper (2004) that bepengaruh employee satisfaction positively to the development of human capital. Job satisfaction has a considerable influence on the development of human capital. Because according to the Ndaraha Davis and Newstrom (1997), that job satisfaction can be demonstrated with feeling happy or unhappy workers to work.

Empirical conditions that occur in the development of human capital in manufacturing companies going public, is always to improve the quality of life of employees, by way of health and safety programs, provide scholarships to children of employees who excel, providing old age benefits, job bonuses, and promoting employees the berpretasi. Implications of these findings for human resource managers of manufacturing firms going public is that the development of human capital can be improved by increasing employee satisfaction, and fulfillment through improved quality of life for themselves and the families.

\section{Conclusions, Recommendations And Limitations}

From the research that has been conducted on the effect of the external and internal environment to the development of human capital in manufacturing companies going public in Indonesia, it can be concluded as follows:(1)the external environment positive and significant impact on the planning and management of human resources, education and training. Manufacturing firms going public, always pay attention to changes in economic, social, cultural, technological, political / legal and demographic, and is associated with changes in the planning and management of human resources such as, scheduling and technical training, technical guidance by technicians from abroad and always adapt to the development trend technology, industry, and market education and training to employees to improve the quality of the resources, capabilities, and competencies, (2) the external environment and a significant positive effect on the development of human capital, as some foreign investors direct placing of personnel, expertise and management at the company to synchronize management and technology transfer between parent and subsidiary companies, (3) the external environment does not significantly influence employee satisfaction, employee performance and recognition, and increased employee, because in general management of the company is still holding on to the company's initial strategy to stock price changes, both in the conditions bullish and the stock price declined on bearish conditions, (4) The internal environment positive and significant impact on human resource planning and management, quality improvement personnel,implementation of education and training, employee performance improvement and recognition, employee satisfaction, and the development of human capital in manufacturing companies going public, (5)Preparation of human resource planning and management, quality improvement personnel, implementation of education and training, employee performance improvement and recognition, employee fulfillment support the development of human capital in manufacturing companies going public.

Recommendations can be given to manufacturing companies going public are: (1) the need to develop Human Capital Master Plan (HCMP) which is a framework of the gradual development of human capital in the firm next period, (2) preparation of human resources planning and management, quality improvement personnel, implementation of education and training, employee performance improvement and recognition, employee fulfillment, and human capital development in manufacturing companies go public, should be reinforced by strengthening the internal environment support such as preparation of Strategic HR development, (3) need to start a tradition with a capital system alignment activities and human resources management system optimization of the flow of human capital framework among the company's employees. Companies need to strengthen human capital and accelerate system performance improvement of human resources on an ongoing basis, so it can happen and HR performance acceleration capabilities significantly to support the achievement of corporate objectives, (4) it was time the company set a new systemic approach in developing human capital, 
because human capital management as well as a system designed to improve the performance of employees and the company, as well as to create a sustainability competitive advantage through the development of the company's employees.

This study has several limitations that this study found no direct effect of the external environment that supports the strengthening of human capital in manufacturing companies going public in Indonesia. Found no effect of changes in the external environment, because the company's strategy has not bridge the human resource flexibility with changes in the external environment. In addition, this study is limited to changes in the external environment and internal environment support, but did not discuss more about the company's strategic flexibility in the development of human capital in manufacturing companies going public. It is necessary for further study of the flexibility of the company's strategy in the development of human capital, the manufacturing company go public in Indonesia.

\section{References}

[1]. Anonymous. 2005. Towards Human Capital Management: Building Competitive Advantage through People. Dibawakan pada seminar LPPI.

[2]. Ancok, Djamaluddin.2005. Human Capital in Organizations, Journal of Human Capital Management.

[3]. Davenport, T.O. 1999. Human Capital: What it is and Why People Invest it. Jossey-Bass: San Francisco.

[4]. Dharma, S., 2004. Human Capital Formation and Strategy Innovation, Entrepreneurship, No.. 9, Year XXXIII, September: 25-30. Edratna.2008. Human Capital Management : Bagaimana Strategi meningkatkan Competitive Advantage melalui Karyawan? Jurnal :http://edratna. wordpress. com/2008/06/05/human- capital -management.

[5]. Fitz-ent, Jac, 2000. The ROI of Human Capital, American Management Association.

[6]. Galunic D.C. \& Anderson, E. 2000. From Security to Mobility: Generalized Investments in Human Capital and Agent Commitment. Organization Science, 11(1), 1-20. http://www.jstor.org/stable/2640402.

[7]. Gamal, Merza.2007. Placing HR as Human Capital, Daily online, http:www. kabarindonesia. com/berita.php/pil=10\&dn=200710261, January 2011. Huselid Mark. A. 2005. The Workforce Scorecard, Managing Human Capital to Executive Strategy.

[8]. Ingham Jon. 2002. Strategic Human Capital Management, Creating Value Through People.

[9]. Markus, R. dan B. Santoso. 2006. Employee Opinion Survey, Human Capital No.29, Agustus: 36-39.

[10]. Mayo, A., 2000. "The Role of Employee Development in The Growth of Intellectual Capital", Personal Review, Vol. 29, No. 4. http://www.emerald-library.com.

[11]. Merza Gamal.2007. Placing HR As Human Capital, Journal, http://mail.yahoo.com

[12]. Pennings,J.M.,Lee K and Van Witteloostuijn A.1998. Human Capaital, Social Capital and Firm Dissolution, Academy of Management, Journal, Vol.41,pp.425-40.

[13]. Rachmawati, D., F. Wulani, and C. E. Susilowati. , 2004. Intellectual Capital and Business Performance: Empirical Study on Industry in Indonesia, International Seminar on Management and Research Conference, Bali Sanur Beach Hotel, FE-University of Indonesia, August: 1-21.

[14]. Rachmawati, D., and F. Wulani. , 2004. Human Capital and Regional Performance: A Case Study in East Java, Research APTIK, April: 1-73.

[15]. Rival, Veirhzal.,2009. Islamic Human Capital-From Theory to Practice Management Resource-Islami, PT.RajaGrafindo Persada, Jakarta.

[16]. Sawarjuwono, T., and A. P. Kadir. , 2003. Intellectual Capital: Treatment, Measurement and Reporting, Journal of Accounting and Finance Vol.5, No.1, May: 35-57.

[17]. Setyanto,R. P. Measurement of Human Capital Opportunities for the Department of Human Resources to Serve as Strategic Partner Bisiness, Entrepreneur 10, Year XXXIII, October 2004: 18-22

[18]. Sheila.2008. 10 Responses to Human Capital Management, Human Capital Management Journal, http://ronawajah. wordpress.com/008/03/25/manajemen-human-capital.

[19]. Stewart, Thomas. A. 1997. Intelectual Capital. Doubleday Dell Publishing Group, Inc, New York.

[20]. Sudrajat, AAN. 2010. Managemenet Human Capital, Human Capital Journal, http: //aansudrajat69.blogspot, com/2010/12/ managemnt-human-capital.

[21]. Wayne,S.J., Robert C. Liden, Maria I. Kraimer, dan Isabel K. Graf. 1999. The Role Of Human Capital, Motivation, and Supervisor Sponsorship In Predicting Career success. Journal of Organizational 